sentence on p. 522, where the authors speak of " . . the hygroscopic salts which are the most effective anti-static agents ..." ; but these lapses are few. In general, the book can be warmly recommended to all textile physizists who can afford to pay the price. P. S. H. HENRY

\section{THE CRIPPLED MIND}

The Biology of Mental Defect

By Prof. L. S. Penrose. Third edition, completely revised with the assistance of J. M. Berg and Helen Lang-Brown. Pp. xxiv $+374+8$ plates. (London: Sidgwick and Jackson, Ltd., 1963.) 42s. net.

HIS book is a new edition of Ponrose's classic revised by the author and two of his assistants, J. M. Berg and Helen Lang-Brown. It is an excellent book, and gives the latest knowledge of this difficult subject.

Forty yoars ago mental deficiency was regarded as more or less an impenetrable mystery. Not that many felt it was worth while spending their time trying to investigate it. Indoed, it was the most disregarded waste-land of a neglected area of medicine. Psychiatry was considered unwortby of the orthodox physician's interest and mental deficiency more or less hopeless from the start. Imbeciles were herded into vast buildings which were little better than prisons, and idiots put into special hospitals where they were merely kept alive. There was practically no attempt to understand the condition, and any idea of treatment or prevention would have aroused ridicule.

Naturally, the literature devoted to such a condition was on a similar level. Text-books were fow and devoted mainly to anecdotal cases on which were built theories based on conjecture. These were copied from one textbook to another and dated back to such theorists as Lombroso with his celebrated ideas of 'degeneracy', which was an inherited state and condemned the sufferer not only to a hopeless life but also any progeny he might have to a similar fate. Indeed, according to Mott, any children of a defective were due to an even worse ond because of his theory of 'anticipation' which implied that once the germ plasm was damaged it tended to deteriorate more and more through the generations. Another theory of that time was 'blastophoria', or damage to the germ tissue, put forward so enthusiastically by Forel. He believed that this damage was caused by alcohol and similar poisons, in spite of the fact that in many cases there was no particle of evidence that the parents had ever used alcohol or suffered from any form of poisoning.

These theories became modified by time, and it was thought that mental defect was due to injury to the brain through traume or infectious disease. This was usually attributed, since it was possible to detect that the child was abnormal at birth, to some intra-uterino condition. The alternative view was that defect was caused by 'neuropathic diathesis' which was inherited, and was only a more scientifically sounding name for Lombroso's 'degeneracy'.

All these theories were blown away by the patient work of Penrose, who produced statistics which shattered them. In 1933 he published his book, Mental Defect, and suggested that the condition was due to a multiplicity of causes. He followed this up with statistical proof in his Colchester Survey for the Medical Research Council in 1938. His Biology of Mental Defect, published in 1949 and revised in 1953, was soon a classic, and tho new edition will be unchallenged. In it he reviews the new developments. The great discovery that such conditions as mongolism are due to cytological abnormalities, the commonest being the extra ehromosome. Again the revelation of the biochemical factor, phenylketonuria, is likely to lead to other advances.

J. B. S. Haldane, who writes a foreword to the new edition, suggests that these discoverios will finally lead to the elimination of a quarter of the defectives. This is true, but the discovery of where to look and the sort of advances which can be made will inevitably lead to other points of progress.

One can sum up by saying that this excellent book should be in the possession of every psychiatrist, geneticist and research worker interested in mental defect. He will find in the descriptions valuable ideas, and in the forty-one pages of references material for a great deal of futuro work.

The book is well bound in dark blue eloth, has clear print, and a full index.

Clifford Alien

\section{ARCH/EOLOGY IN THE TRANSVAAL}

\section{Prehistory of the Transvaal}

A Record of Human Activity. By Revil Mason. Pp. xxiv +498 (257 figures). (Johannesburg: Witwatersrand University Press, 1962.) R. 6 ; 60s.; 8.70 dollars.

$\mathrm{D}^{\mathrm{n}}$ R. MASON'S book is unfortunate in that it is published at a time when inter-disciplinary studies of archæological remains are opening up new possibilities of understanding prehistoric peoples. The application of scientific techniques, such as pollen analysis and radiocarbon dating and the statistical analysis of assemblages of artefacts, are together forming a basis for future studies of the relationship of man to time and environment.

It is, therofore, disconcerting to read that in Dr. Mason's opinion little reliable work has been done in the Transvaal on phenomena which indicate climatic change and that prehistoric remains are also not likely to provide an accurate reflexion of environment. In consequence, environment is discussed in terms of a simple territorial division for descriptive purposes only. Elsewhere, he states that it seems doubtful if the radiocarbon dates from the Transvaal can be accepted and also that geological interpretations so far put forward are often unsatisfactory. It is, therefore, apparent that this book does not offer the fuller picture of prehistory to which archæologists in recent years have become accustomed and that, by and large, Dr. Mason has not been able to apply in full the correctives of available scientific techniques to typological hypotheses.

There is, however, an analysis of the artefacts from many sites in the Transvaal. For the most part this is a simple numerical analysis of defined tool categories. In defining these categories Dr. Mason is faced with the dilemma of whether to make them so wide that essential differences may be obscured or so numerous and narrow that they may be ill defined. He has chosen the former alternative and on this basis has attempted even an inter-continental comparison between Transvaal sites and two Mousterian sites in France. Without geographical limitation or environmental comparison it is doubtful whether or not comparisons based on such a small sample are of value. Indeed, simple numerical or metrical analyses of tool types are not likely to be regarded in future as sufficient, in view of the more complex statistical analyses now used in Europe and the United States. There is, however, a body of information of use to research workers.

There are, in addition, many drawings and photographs of artefacts, some imaginative drawings of life in tho Stone Age which may have some popular appeal and which have been executed with attention to the known facts, and some excellent reproductions of rock art. There is a good bibliography.

On the whole the book may appeal more to the laymen than to the professional archæologist, but Dr. Mason's resolute refusal to accept ready-made conclusions drawn from evidence which he believes to be inadequate or wrongly interpreted is of value to African archæology, and so are his attempts to solve debatablo field problems by direct personal action.

E. S. Higas 